$\mathrm{DE}$

M E D I C I N A

T R O P I C A L

$\mathrm{DE}$

S ÃO PAULO

JOURNAL OF THE SÃO PAULO INSTITUTE OF TROPICAL MEDICINE

(1)Universidade Federal de Mato Grosso do Sul, Faculdade de Medicina, Programa de Pós-Graduação em Doenças Infecciosas e Parasitárias, Campo Grande, Mato Grosso do Sul, Brazil

(2)Universidade Federal de Mato Grosso do Sul, Centro de Ciências Biológicas e da Saúde, Programa de Pós-Graduação em Enfermagem, Campo Grande, Mato Grosso do Sul, Brazil

(3)Fundação Instituto Oswaldo Cruz, Laboratório Interdisciplinar de Pesquisas Médicas, Rio de Janeiro, Rio de Janeiro, Brazil

Correspondence to: Minoru German Higa Júnior

Universidade Federal de Mato Grosso do Sul,. Laboratório de Parasitologia, Clínica/ LAC/CCBS, Caixa Postal 549, CEP 79070900, Campo Grande, MS, Brazil.

E-mail: minorugerman@ hotmail.com

Received: 2 June 2017

Accepted: 18 October 2017

\section{Intestinal parasitism among waste pickers in Mato Grosso do Sul, Midwest Brazil}

Minoru German Higa Júnior ${ }^{1}$, Wesley Márcio Cardoso², Sabrina Moreira dos Santos Weis ${ }^{1}$, Adriana de Oliveira França ${ }^{1}$, Elenir Rose Jardim Cury Pontes ${ }^{1}$, Patrícia Vieira da Silva', Márcia Pereira de Oliveira ${ }^{3}$, Maria Elizabeth Moraes Cavalheiros Dorval ${ }^{1}$

\section{ABSTRACT}

The purpose of this study was to estimate the prevalence of intestinal parasites in both cooperative-affiliated and independent waste pickers operating at the municipal sanitary landfill in Campo Grande, Mato Grosso do Sul, Brazil, and associate these findings with hemoglobin, eosinophils, vitamin A and C levels and interleukin 5 and 10 (IL-5 and IL-10) production. Biological samples were collected, in addition to clinical, epidemiological, and sociodemographic data. Stool analyzes were based on sedimentation by centrifugation and on spontaneous sedimentation. High-performance liquid chromatography was used to determine vitamin A and C levels. ELISA was employed to quantify interleukins. Intestinal parasites were found in 29 of the 66 subjects assessed (43.9\%). Endolimax nana (22.7\%), Entamoeba coli (21.1\%), Giardia lamblia (6.1\%), Entamoeba histolyticalE. dispar (4.5\%), and Ascaris lumbricoides $(4.5 \%)$ were the most prevalent species. Pathogenic parasites were detected in 11 individuals (16.7\%). Hypovitaminoses A and $\mathrm{C}$ were detected in 19.6\% (13/66) and 98.4\% (65/66) of subjects, respectively. IL-5 and IL-10 production was observed in $21(31.8 \%)$ and $32(48.4 \%)$ subjects, respectively. Infection with pathogenic intestinal parasites was not a cause of vitamin A and C deficiency or IL-5 and IL-10 production among these workers.

KEYWORDS: Occupational health. Solid waste. Parasites. Vitamins. Hypovitaminose A. Hypovitaminose C. Cytokines. Waste pickers. Parasitosis. Intestinal parasitism. Intestinal parasitosis.

\section{INTRODUCTION}

Worldwide, consumerist lifestyles have led to increased generation of solid waste $^{1,2}$. Waste pickers are typically low-income individuals who collect, sort, process, transform, and market recyclable materials. Frequent exposure to waste materials renders these workers particularly vulnerable to health hazards ${ }^{3,4}$. In addition, the limited awareness on the connection between waste exposure and disease acquisition (e.g., viral, bacterial, fungal, protozoan and helminth infections) among these workers makes the occupational health of this group a fertile field for studies and interventions addressing health policies and the health-disease process $^{5,6,7}$.

Intestinal parasitoses, a public health problem in Brazil, are associated with poor sanitation and living conditions, as well as poor personal, food-related and environmental hygiene, constituting a major cause of morbidity in humans. Intestinal parasitoses in association with malnutrition will particularly impact 
on physical, psychosomatic and social developments ${ }^{8}$. Although nutritional deficiencies can influence the onset and course of parasitic infections, immunopathological and immunoprotective mechanisms involved have not been fully clarified ${ }^{9}$.

Given the scarcity of investigations on intestinal parasitosis among waste pickers, the present study was designed to estimate the prevalence of infection among this population in Campo Grande, the capital city of Mato Grosso do Sul State, Midwest Brazil, and to associate this condition with hemoglobin, eosinophils, vitamin $\mathrm{A}$ and $\mathrm{C}$ levels and interleukin 5 (IL-5) and 10 (IL-10) production. A further objective was to make this population segment more visible to the Brazilian Unified Healthcare System (SUS), thus facilitating access to and humanizing healthcare.

\section{MATERIAL AND METHODS}

The investigation was conducted in Campo Grande at two waste picker cooperatives (Coopermaras and Coopernova) and at the municipal sanitary landfill, from June 2014 to June 2015.

Waste pickers registered in the cooperatives and those working independently at the landfill were invited to join the study.

The study inclusion criteria were working as a waste picker and/or sorting recyclable materials, aged 18 years or older and the provision of a written informed consent.

Individuals with impaired capacity to exercise civil rights and fulfill civil duties or those with intellectual disabilities were excluded, as were those for whom special types of consent are mandatory - e.g., members of Quilombola groups (inhabitants of ethnically homogeneous, typically isolated rural communities of descendants of former Afro-Brazilian slaves) or indigenous communities.

After providing informed written consent, participants were interviewed for collection of sociodemographic (sex, age range, educational level, household income), clinical (diarrhea, abdominal pain, nausea, vomiting, weight loss, hyporexia) and epidemiological data (personal and food hygiene, basic sanitation), using customized forms. The interviews were conducted by trained health professionals.

Stool samples were collected in universal specimen flasks containing MIF fixative (distilled water, merthiolate, formaldehyde, glycerin) and stored at room temperature until processed. Parasitological examination was performed using centrifugation-sedimentation ${ }^{10}$ and spontaneous sedimentation ${ }^{11}$. Two slides per sample were examined.

Blood samples were collected by peripheral venous puncture.
Automated blood counts, performed on a Sysmex XE-2100D analyzer, employed $2 \mathrm{~mL}$ of whole blood treated with anticoagulant and EDTA. Differential leukocyte counts were confirmed with blood smears stained with May-Grünwald-Giemsa. For both sexes, anemia was defined as a hemoglobin level below $13.5 \mathrm{~g} / \mathrm{dL}$. Eosinophilia was defined as a relative count above $8 \%$.

Vitamins $\mathrm{A}$ and $\mathrm{C}$ were quantified by high-performance liquid chromatography, using Chromsystems Diagnostics kits (Chromsystems Instruments \& Chemicals $\mathrm{GmbH}$, Gräfelfing, Germany). Normal values for vitamins A and C were defined as $0.3-0.7$ and $4.6-15.0 \mathrm{mg} / \mathrm{L}$, respectively.

Human IL-5 Mini ELISA Development and Human IL-10 Mini ELISA Development kits (Peprotech, Rocky Hill, NJ, USA) were used to quantify IL-5 and IL-10, respectively. All quantification procedures were conducted at the Interdisciplinary Laboratory of Medical Research of the Oswaldo Cruz Foundation, Rio de Janeiro.

Carriers of pathogenic parasites were prescribed metronidazole (for protozoans) and albendazole (for helminths). Dietary guidance was provided to prevent vitamin $\mathrm{A}$ and $\mathrm{C}$ deficiency and intestinal parasitosis.

Data were subjected to the chi-square test with Yates's correction, the chi-square test for trend, and the Fisher's exact test, using Epi Info 3.5.3 and BioEstat 5.0 software. Prevalence ratios were calculated with $95 \%$ confidence intervals. Associations were considered statistically significant when $p<0.05$.

The study design and the informed consent form were approved by the Universidade Federal de Mato Grosso do Sul (UFMS) Ethics Committee for Research on Humans (approval No 467.624).

\section{RESULTS}

From the total of 66 subjects, $43.9 \%$ (32.0-55.9\%, 95\% CI) tested positive for intestinal parasites. A $16.7 \%$ prevalence $(7.7-25.7 \%, 95 \% \mathrm{CI} ; 11 / 66)$ was found for pathogenic species. Endolimax nana (22.7\%), Entamoeba coli $(21.1 \%)$, Giardia lamblia (6.1\%), Entamoeba histolytica/E. dispar (4.5\%) and Ascaris lumbricoides $(4.5 \%)$ were the most prevalent pathogenic parasites (Table 1).

The age of subjects ranged from 19 to 67 years old. Males accounted for $60.6 \%$ of the sample. Most subjects $(65.1 \%)$ had never attended school or completed elementary education. Regarding monthly income, $42.4 \%$ of participants earned one minimum wage or less (Table 2).

The prevalence of parasitism $(n=29)$ did not differ significantly by gender, age group, educational level or household income. 
Table 1 - Distribution of fecal parasitological findings among waste pickers. Campo Grande, MS, Brazil, 2014-2015 $(n=66)$

\begin{tabular}{lcc}
\hline & $\mathbf{N}^{*}$ & $\%$ \\
\hline Parasitosis & 37 & 56.1 \\
$\quad$ Negative & 29 & 43.9 \\
$\quad$ Positive & & \\
Commensal protozoans & 15 & 22.7 \\
$\quad$ Endolimax nana & 14 & 21.2 \\
$\quad$ Entamoeba coli & 2 & 3.0 \\
$\quad$ Blastocystis hominis & 1 & 1.5 \\
$\quad$ lodamoeba bütschlii & & \\
Pathogenic protozoans & 4 & 6.1 \\
$\quad$ Giardia lamblia & 3 & 4.5 \\
$\quad$ Entamoeba histolytica/E. dispar & & \\
Helminths & 3 & 4.5 \\
$\quad$ Ascaris lumbricoides & 1 & 1.5 \\
$\quad$ Strongyloides stercoralis & 1 & 1.5 \\
\hline Hookworms &
\end{tabular}

*One or more species possible per individual.

Among the 66 participants, $97.0 \%$ reported having access to piped water (3.0\% did not respond) and $95.5 \%$ reported the habit of washing food items before consumption ( $4.5 \%$ did not respond). The prevalence of parasitism $(n=29)$ was not significantly influenced by the availability of a sewage system in the place of residence, the habit of wearing shoes, or the habit of washing hands before meals and after using the bathroom (Table 3 ).

No significant differences in the proportion of subjects presenting or not with diarrhea, abdominal pain, nausea, vomiting, weight loss, hyporexia, anemia, eosinophilia, hypovitaminoses A or C, or IL-5 and IL-10 production in response to pathogenic parasites were observed $(n=11)$ (Table 4).

Regarding the three individuals diagnosed with pathogenic intestinal parasites and eosinophilia, one was infected with Giardia lamblia and two with Ascaris lumbricoides. Hypovitaminosis C was detected in all subjects except one. Among the three individuals with IL-5 production and pathogenic parasites, two had helminthiasis, a possible cause of the generation of this cytokine.

\section{DISCUSSION}

This is the first study to investigate intestinal parasitosis in waste pickers in Midwest Brazil. A 43.9\% prevalence of parasitosis was detected, but comparisons are limited by the lack of investigations on intestinal parasitism in adults, particularly among waste pickers, in Brazil. Nunes et al. ${ }^{12}$, investigating 22 garbage collectors in Patrocínio county, Minas Gerais State, found a higher prevalence of nonpathogenic Entamoeba coli and Endolimax nana, consistent with the present findings. Although these parasites are human gut commensals, their detection can reveal higher

Table 2 - Sociodemographic variables investigated among waste pickers. Campo Grande, MS, Brazil, 2014-2015 ( $n=66$ )

\begin{tabular}{|c|c|c|c|c|c|}
\hline \multirow{2}{*}{ Variable } & \multicolumn{2}{|c|}{ Parasitized } & \multicolumn{2}{|c|}{ Non-parasitized } & \multirow{2}{*}{$p$} \\
\hline & $\mathbf{N}$ & $\%$ & $\mathbf{N}$ & $\%$ & \\
\hline Sex & & & & & (1) 0.969 \\
\hline Female & 12 & 46.1 & 14 & 53.9 & \\
\hline Male & 17 & 42.5 & 23 & 57.5 & \\
\hline Age range (years) & & & & & (1) 0.827 \\
\hline $20-40$ & 15 & 46.9 & 17 & 53.1 & \\
\hline$>40$ & 14 & 41.2 & 20 & 58.8 & \\
\hline Educational level & & & & & (2) 0.700 \\
\hline No data* & - & - & 3 & 100.0 & \\
\hline Incomplete primary education or no formal education & 20 & 46.5 & 23 & 53.5 & \\
\hline Middle school diploma (8-9 years) & 6 & 50.0 & 6 & 50.0 & \\
\hline Incomplete high school & 2 & 40.0 & 3 & 60.0 & \\
\hline High school diploma (11-12 years) & 1 & 33.3 & 2 & 66.7 & \\
\hline Household income (minimum wages) & & & & & (2) 0.269 \\
\hline No data* & - & - & 2 & 100.0 & \\
\hline$\leq 1.0$ & 12 & 42.9 & 16 & 57.1 & \\
\hline $1.1-2.0$ & 10 & 38.5 & 16 & 61.5 & \\
\hline$>2.0$ & 7 & 70.0 & 3 & 30.0 & \\
\hline
\end{tabular}

${ }^{*}$ Excluded from statistical calculations. (1) Yates-corrected Chi-squared test. (2) Chi-squared test of trends. 
Table 3 - Other variables investigated among waste pickers. Campo Grande, MS, Brazil, 2014-2015 $(n=66)$

\begin{tabular}{|c|c|c|c|c|c|}
\hline \multirow{2}{*}{ Variable } & \multicolumn{2}{|c|}{ Parasitized } & \multicolumn{2}{|c|}{ Non-parasitized } & \multirow{2}{*}{$p$} \\
\hline & $\mathbf{N}$ & $\%$ & $\mathbf{N}$ & $\%$ & \\
\hline Sewage system & & & & & 0.875 \\
\hline No data* & 1 & 50.0 & 1 & 50.0 & \\
\hline No & 27 & 42.9 & 36 & 57.1 & \\
\hline Yes & 1 & 100.0 & - & - & \\
\hline Habit of wearing shoes & & & & & 0.857 \\
\hline No data* & 2 & 66.7 & 1 & 33.3 & \\
\hline No & 1 & 100.0 & - & - & \\
\hline Yes & 26 & 41.9 & 36 & 58.1 & \\
\hline Habit of washing hands before meals & & & & & 0.645 \\
\hline No data* & 2 & 66.7 & 1 & 33.3 & \\
\hline No & - & - & 2 & 100.0 & \\
\hline Yes & 27 & 44.3 & 34 & 55.7 & \\
\hline Habit of washing hands after using bathroom & & & & & 0.560 \\
\hline No data* & 2 & 66.7 & 1 & 33.3 & \\
\hline No & 1 & 20.0 & 4 & 80.0 & \\
\hline Yes & 26 & 44.8 & 32 & 55.2 & \\
\hline
\end{tabular}

*Excluded from statistical calculations. ${ }^{(1)}$ Fisher's exact test.

Table 4 - Clinical and laboratory variables investigated among waste pickers. Campo Grande, MS, Brazil, 2014-2015 ( $n=66)$

\begin{tabular}{|c|c|c|c|c|c|}
\hline \multirow{3}{*}{ Variable } & \multicolumn{4}{|c|}{ Pathogenic intestinal parasites } & \multirow{3}{*}{$\boldsymbol{p}^{(1)}$} \\
\hline & \multicolumn{2}{|c|}{ Yes $(n=11)$} & \multicolumn{2}{|c|}{ No $(n=55)$} & \\
\hline & $\mathbf{N}$ & $\%$ & $\mathbf{N}$ & $\%$ & \\
\hline \multicolumn{6}{|l|}{ Clinical variables } \\
\hline Diarrhea & 4 & 36.4 & 20 & 36.4 & 1.000 \\
\hline Abdominal pain & 3 & 27.3 & 25 & 45.5 & 0.440 \\
\hline Nausea & 4 & 36.4 & 17 & 30.9 & 0.976 \\
\hline Vomiting & 4 & 36.4 & 14 & 25.5 & 0.687 \\
\hline Weight loss & 3 & 27.3 & 18 & 32.7 & 1.000 \\
\hline Hyporexia & 5 & 45.5 & 14 & 25.5 & 0.329 \\
\hline \multicolumn{6}{|l|}{ Laboratory variables } \\
\hline Anemia & 1 & 9.1 & 10 & 18.2 & 0.822 \\
\hline Eosinophilia & 3 & 27.3 & 8 & 14.6 & 0.527 \\
\hline Hypovitaminosis A & 3 & 27.3 & 10 & 18.2 & 0.742 \\
\hline Hypovitaminosis C & 11 & 100.0 & 54 & 98.2 & 1.000 \\
\hline IL-5 & 3 & 27.3 & 18 & 32.7 & 1.000 \\
\hline IL-10 & 3 & 27.3 & 29 & 52.7 & 0.225 \\
\hline
\end{tabular}

(1) Fisher's exact test.

degrees of exposure to fecal contamination, thus serving as an indicator of socio-sanitary conditions ${ }^{13}$.

The prevalence of Ascaris lumbricoides of $4.5 \%$ found in the present study was far lower than that of $25.0 \%$ detected by Sposito et al. ${ }^{14}$ among 16 waste pickers in Pelotas and Capão do Leão, counties in the Southern State of Rio Grande do Sul.
In Pelotas, also in the State of Rio Grande do Sul, another study ${ }^{15}$ detected Trichuris trichiura among waste pickers. An explanation for the absence of this species in the present sample is that infections with this helminth are more common in coastal areas with a wet climate and sandy soil ${ }^{16}$.

A fixative was employed to preserve all the fecal samples, which may explain the low frequency of 
Strongyloides stercoralis and the absence of other helminth species, whose detection requires specific techniques that were not used in the present investigation.

Generally, low purchasing power and the educational level indicate scant knowledge available on intestinal parasites prevention, and thus a higher prevalence of parasitism. In the present study, however, the opposite was observed as non-parasitized individuals predominated. A possible reason for this finding is the indiscriminate use of antiparasitic drugs. Even without the support of consistent official data, Frei et al. ${ }^{17}$ have speculated that a decreased prevalence resulting from prophylactic antiparasitic medication can actually mask poor underlying health and educational conditions, delaying other prophylactic measures, as well as efforts to improve sanitation and sanitary education.

Intestinal parasitoses can cause diarrhea, abdominal pain, nausea, vomiting, weight loss and hyporexia but, in the present sample, these events were more frequent in carriers of non-pathogenic parasites and in individuals testing negative for intestinal parasites. Absence of signs or symptoms, however, does not rule out parasitic infections, given the frequency of asymptomatic cases, as well as of signs and symptoms that overlap with those of intestinal parasites ${ }^{18}$.

Intestinal parasitic infections can cause or contribute to the development of anemia, together with factors such as unbalanced, low-iron diets, antacids (which decrease iron absorption), gastroplasty and presence of urogenital or gastrointestinal bleeding ${ }^{19}$.

Parasite-induced peripheral and tissue eosinophilias are primarily dependent on production of IL-5, responsible for Th-2 lymphocyte differentiation and release from bone marrow into peripheral blood. These types of eosinophilia are common among patients infected with trematodes, cestodes, and nematodes. Eosinophilia caused by Giardia lamblia remains poorly investigated ${ }^{20}$. In the present study, allergic reactions may have been a cause of the elevated eosinophil counts observed in cases of non-pathogenic parasitism or negative stool tests ${ }^{21}$.

Among the three individuals presenting with IL-5 production and pathogenic parasites, two had helminthiasis, a possible cause of generation of this cytokine. The same was observed for IL-10. IL-5 and IL-10 production in individuals with negative stool tests or carriers of nonpathogenic parasites may result from atopic diseases or allergic reactions.

To our knowledge, no previous studies have associated hypovitaminosis A with the presence of intestinal parasites in waste pickers, and biochemical surveys of vitamin A deficiency in Midwest Brazil are scarce s2,23. $^{23}$

Although male gender has been reported as a factor associated with the etiopathogenesis of hypovitaminosis $\mathrm{D}^{24}$,
10 of the 13 vitamin A-deficient subjects in the present sample were women. Morbidity and mortality rates associated with parasitism, as well as a synergism of this condition with vitamin A deficiency point out the importance of evaluating at-risk populations in order to guide the design and implementation of prophylactic interventions ${ }^{22}$.

The detection of hypovitaminosis $\mathrm{C}$ in the present sample, however, merits further discussion. Unbalanced diets may be a cause of this condition. In cross-sectional studies, serum vitamin $\mathrm{C}$ levels have indicated better nutritional status among children who were not infected with, or treated for Ascaris lumbricoides than among those infected but left untreated ${ }^{25}$. In addition, it has been suggested that vitamin supplementation may benefit immune responses, helping to prevent cancer and heart disease while delaying cataract development ${ }^{26}$.

Non-pathogenic protozoans were more prevalent in the present sample. The sociodemographic and sanitation as well as hygiene-related variables investigated in the present study did not prove to be significant as factors for intestinal parasitic infections. Despite the diagnosis of pathogenic parasites, the clinical manifestations observed were not secondary to intestinal parasitism. Infection with pathogenic parasites was not a cause of hypovitaminoses $\mathrm{A}$ and $\mathrm{C}$ and production of IL-5 and IL-10.

A limitation of this study was the small number of subjects. Addressing health problems that affect the general population requires concerted efforts from all sectors of society, as well as measures to ensure that all members will have access to an effective guidance toward the improvement of the quality of life.

\section{CONFLICT OF INTEREST}

All the authors declare the absence of conflict of interest.

\section{ACKNOWLEDGMENTS}

The authors wish to thank Zelia Soares da Silva and Patricia Daniele Matos Ferreira Gomes (Laboratory of Clinical Parasitology, UFMS) for the technical support. We are also grateful to Professors Ana Rita Coimbra Motta de Castro and Solange Zacalusni Freitas, for making their laboratory facilities available.

\section{AUTHORS' CONTRIBUTION}

MGHJ jointly conceived the study with MEMCD and participated in data collection, laboratory testing, statistical analysis and writing the article. WMC contributed to data 
collection. SMSW participated in data collection and laboratory tests. AOF collaborated in the drafting and critical review of the manuscript. ERJCP contributed to the statistical analysis. PVS worked on data collection. MPO performed laboratory exams and collaborated in the statistical analysis. In addition to participating in the conception of the study, MEMCD conducted laboratory tests, wrote the manuscript and provided a critical review throughout its development.

\section{REFERENCES}

1. Graudenz GS. Indicadores infecciosos e inflamatórios entre trabalhadores da limpeza urbana em São Paulo. Rev Bras Saude Ocup. 2009;34:106-14.

2. Santos GO, Silva LF. Os significados do lixo para garis e catadores de Fortaleza (CE, Brasil). Cien Saude Colet. 2011;16:3413-9.

3. Brasil. Decreto ${ }^{\circ} 7.405$, de 23 de dezembro de 2010. Institui o programa Pró-Catador, denomina Comitê Interministerial da Inclusão de Catadores de Lixo, criado pelo decreto de 11 de setembro de 2003, dispõe sobre sua organização e funcionamento, e dá outras providências. Diário Oficial da União, Brasília, 24 dez 2010. [cited 2017 Oct 18]. Available from: http://www.planalto.gov.br/ccivil_03/_ato20072010/2010/decreto/d7405.htm

4. Cavalcanti Neto AL, Rêgo AR, Lira A, Arcanjo JC, Oliveira MM. Consciência ambiental e os catadores de lixo do lixão da cidade do Carpina - PE. Rev Eletron Mestr Educ Ambient. 2007;19:99-109.

5. Lazzari MA, Reis CB. Os coletores de lixo urbano no município de Dourados (MS) e sua percepção sobre os riscos biológicos em seu processo de trabalho. Cien Saude Colet. 2011;16:343742.

6. Porto MF, Juncá DC, Gonçalves RS, Filhote MI. Lixo, trabalho e saúde: um estudo de caso com catadores em um aterro metropolitano no Rio de Janeiro, Brasil. Cad Saude Publica. 2004;20:1503-14.

7. Alvarado-Esquivel C, Liesenfeld O, Márquez-Conde JA, Cisneros-Camacho A, Estrada-Martínez S, Martínez-García SA, et al. Seroepidemiology of infection with Toxoplasma gondii in waste pickers and waste workers in Durango, Mexico. Zoonoses Public Health. 2008;55:306-12.

8. Ludwig KM, Frei F, Alvares Filho F, Ribeiro-Paes JT. Correlação entre condições de saneamento básico e parasitoses intestinais na população de Assis, Estado de São Paulo. Rev Soc Bras Med Trop. 1999;32:547-55.

9. Lawrene CE. Is there a common mechanism of gastrointestinal nematode expulsion? Parasite Immunol. 2003;25:271-81.

10. Blagg W, Schloegel EL, Mansour NS, Khalaf GI. A new concentration technic for the demonstration of protozoa and helminth eggs in feces. Am J Trop Med Hyg. 1954;4:23-8.
11. Hoffman WA, Pons JA, Janer JL. Sedimentation concentration method in Schistosomiasis mansoni. Puerto Rico J Public Health Trop Med. 1934;9:283-91.

12. Nunes AL, Cunha AM, Marçal Júnior O. Coletores de lixo e enteroparasitoses: o papel das representações sociais em suas atitudes preventivas. Cien Educ. 2006;12:25-38.

13. Santos AS, Merlini LS. Prevalência de enteroparasitoses na população do município de Maria Helena, Paraná. Cien Saude Colet. 2010;15:899-905.

14. Sposito NA, Speroto RL, Farias NA. Ocorrência de parasitos intestinais em catadores de resíduos sólidos da região sul do Rio Grande do Sul/Brasil-Dados preliminares. In: XIV Encontro de Pós-Graduação da Universidade Federal de Pelotas; 2012 Oct 30-31. Pelotas: Universidade Federal de Pelotas; 2012. [cited 2017 Oct 18]. Available from: http://www2.ufpel.edu. br/enpos/2012/anais/pdf/CS/CS_00540.pdf

15. Hernandes JC, Corrêa EK, Corrêa LB, Heylmann KK, Pereira VR, Radin J, et al. Coorte coprológica em catadores de uma cooperativa de triagem de resíduos sólidos. Rev Panam Infectol. 2015;17:37-41.

16. Camillo-Coura L. Fatores relacionados à transmissão de geohelmintíases. Rev Soc Bras Med Trop. 1974;8:223-33.

17. Frei F, Juncansen C, Ribeiro-Paes JT. Levantamento epidemiológico das parasitoses intestinais: viés analítico decorrente do tratamento profilático. Cad Saude Publica. 2008;24:2919-25.

18. Tavares W, Marinho LA, editores. Rotinas de diagnóstico e tratamento das doenças infecciosas e parasitárias. $3^{\text {a }}$ ed. São Paulo: Atheneu; 2012.

19. Cançado RD, Chiattone CS. Anemia ferropênica no adulto: causas, diagnóstico e tratamento. Rev Bras Hematol Hemoter. 2010;32:240-6.

20. Fontenele AL, Carvalho PG, Ferreira CH, Girão AB, Teixeira MJ, Queiroz JÁ, et al. Avaliação da dosagem de interleucina-5 e imunoglobulina em pacientes com giardíase com ou sem eosinofilia. Rev Bras Anal Clin. 2006;38:201-6.

21. Tefferi A, Patnaik MM, Pardanani A. Eosinophilia: secondary, clonal and idiopatic. Br J Haematol. 2006;133:468-92.

22. Souza WA, Vilas Boas OM. A deficiência de vitamina A no Brasil: um panorama. Rev Panam Salud Publica. 2002;12:173-9.

23. Graebner IT, Saito CH, Souza EM. Avaliação bioquímica de vitamina A em escolares de uma comunidade rural. J Pediatr (Rio J.). 2007;83:247-52.

24. Santos MA, Rezende EG, Lamounier JA, Galvão MA, Bonomo E, Leite RC. Hipovitaminose A em escolares da zona rural de Minas Gerais. Rev Nutr. 2005;18:331-9.

25. Alves JA, Santos Filho E. Parasitoses intestinais na infância. Pediatr Mod. 2005;41:7-15.

26. Armstrong LE, Maresh CM. Vitamin and mineral supplements as nutricional aids to exercise performance and health. Nutr Rev. 1996;54:S149-58. 